\title{
A Kind of Sustainable Craft Making: Equal and Flexible Participation in Piecing Acehnese Hat ${ }^{*}$
}

\author{
Toshiyuki Sano \\ Nara Women’s University, Nara, Japan
}

\begin{abstract}
Terms of sustainable and sustainability have been employed in various sectors and fields since around 1990. To make a society sustainable needs to find ways of having sustainable local activities. The ways may be to find and revitalize local resources, or to support new life styles by accepting outsider's new ideas. I see those ways often taken from a perspective that the ways require a structure or institutional organization. To explore in-between ways, it would be better to have an alternative perspective and useful to learn from Southeast Asian cases of managing diversity while accepting new ways (cf. Reid, 2015). In this essay, I focus on a sustainable craft making of a men's hat kopiah meuketob in Aceh, Sumatra, which is traditional item for marriage but has been used in various imaginative ways and has been shaping a regional "craft-scape.” I examine such ways and various facets of making the hat and conclude that a lesson from the case for making things sustainable is equal and flexible ways of participating in production processes.
\end{abstract}

Keywords: Aceh, Sumatra, craft, sustainability, flexible participation, women’s work, men’s hat

\section{Introduction}

Terms of sustainable and sustainability have been employed in various sectors and fields since around 1990. To make a society sustainable has become a national agenda everywhere in the world (Kates, Parris, \& Leiserowitz, 2005; UNDP, 2011). To do so, it is necessary that the society be founded on sustainable activities in local communities and it is important to find ways of having them. One way is to find local cultural resources and to promote activities to revitalize them which are worthy to preserve with an expectation that they would become local industries. Something local and affection for locality are assumed to be the basis to sustain the lives in the communities. The other way is to support to create new life styles by accepting human resources from outside with new ideas. As a result of the creation, something non-local to be brought and affection toward locality to be born would bring about sustainable activities in the communities. Even though the in-between ways exit, those ways have been often taken in recent measures and practices and it would take a while for us to know how these would contribute to sustaining the way of healthy living and well-beings.

\footnotetext{
* Acknowledgements: I would like to thank Yuka Matsumoto for providing field collaboration and information of Indonesian resources. I am also grateful to Herawati binti Muhammad Zain for field assistance. This study was supported by a grant-in-aid from the Foundation of Joint Research for Fashion and Clothing Culture, Bunka Fashion Research Institute, Bunka Gakuen University, Tokyo (FY 2010-2011).

Toshiyuki Sano, MS, University of Tokyo; MA and Ph.D., anthropology, Stanford University; Professor of Anthropology, Faculty of Human Life and Environment, Nara Women's University.
} 
As in Japan and other countries alike, since the continuity is a facet of sustainability, the lesson from cases of long-lasting activities influences our thinking of sustainability. For instance, as far as the continuity is concerned, individual passion, family succession and master-apprentice relationships, and official protections as well, have sustained the way of making things traditional over decades or even centuries. So, we tend to see that the way of finding sustainability requires a kind of principled structure or organization. Nevertheless, structural settings have not necessarily associated with making a society sustainable because they are subject to change due to social and natural reasons. I think we need to explore kinds of ways for sustainable lives by shifting from the perspective affected by the structural continuity to a perspective based on actors' sustainable activities (Latour, 2005).

For this, it would be useful to learn more from Southeast Asian cases of managing diversity while accepting new ways as Reid (2015) argues. During my visits to Aceh province, Indonesia, having still the structure-based perspective, I was challenged to rethink it when I realized that it did work to understand some of my findings but did not work with some others. For instance, many tailors who own a shop throughout Aceh traditionally originate from the same old port town, Sigli. This seems to accord with the perspective because there must be a systematic way of producing tailors. However, the structural perspective did not explain me about people's flexible attitude toward traditions in cases such as recent designers' fashion creation within a framework of the Islamic Laws, and women's participation in manufacturing a traditional colorful patchwork-helmet-like men's hat in a village near the tailors' home town. Especially I was impressed by the hat because although it has been for marriage custom, it is used variously in Aceh's landscape, and this seems to be an example of the cultural flow that shapes regional "craft-scape" even before Aceh region was not fully influenced by the globalization which started to be voiced worldwide in the late twentieth century (cf. Appadurai, 1996).

Responding to the challenge, I draw on my field experiences and collections of written materials (see Note 1) during five short-term visits in 2010 and 2011 to Banda Aceh, a capital city, and other places of Aceh province. During my visits, I focused on ways in which Acehnese people make and use the men's hat, kopiah meuketob (hereafter Kopiah) in their lives. The topic derives not merely from the fascinating features of its unusual shape and color combination but from my recognition that its production has been sustained over a century and substantially related to natural disasters and social difficulties such as 2004 earthquake/tsunami striking coastal towns of Aceh and the decades-long separatist conflict before the tsunami. My recognition loomed as I collected pieces of information about actors associated with Kopiah and about historical and geographical aspects of Kopiah and its production sites.

In this essay I piece such a variety of information together to understand the sustainable Kopiah making. Initial key information I obtained from women in Garot village, Pidie Regency of Aceh Province (see Figure 1), was that many women in two sections of the agricultural village eight kilometers away from Sigli, a town on the north-west coast of Sumatra, are engaged in making Kopiah, and that Meulaboh, a town located on the other coast side of Sumatra, is another place where Kopiah was manufactured. One reason Meulaboh is the production site was told by a Garot woman (84 as of 2010) that people of Meulaboh "stole" the skills from Garot. To confirm it is difficult, but it is true that Meulaboh has been long associated with Kopiah. The town is known as the birth/death place of Teuku Umar who gained a hero status for leading courageous battles against Dutch during the late nineteenth century (Smith, 1997, p. 10). It is not difficult to see a connection between the hat and the hero and a connection between the hero and his birth/death place. Then these connections make 
sense that Meulaboh has a large memorial object of kopiah meuketob about ten meters high at a park and a smaller object of it is placed at an intersection in the town proper.

Six years after 2004 tsunami hit Meulaboh, I visited there to see how local women would have been making Kopiah, and I heard from local men that the women who had made it did not survive the tsunami. A woman owner of a craft shop told that she assisted a group of women at one of the housings for the sufferers to start making some craft items for revitalization, but no more Kopiah because there was none who could teach how to make it. A Garot woman told that an attempt was made that Garot women were invited to teach how to make it to Meulaboh women, but the short-time lessons did not result in the revival of Kopiah making. Garot is still the Kopiah making site while Meulaboh became no more. Why is it? To answer it, we look at contrasts between the two places. Garot is a rural small village in wet rice agricultural area away from the coast at no more twenty meters above sea level while Meulaboh is one of the old coastal towns. Because Kopiah craftswomen lived and worked inside the town proper of Meulaboh, they suffered, whereas villagers of Garot were safe from the tsunami.

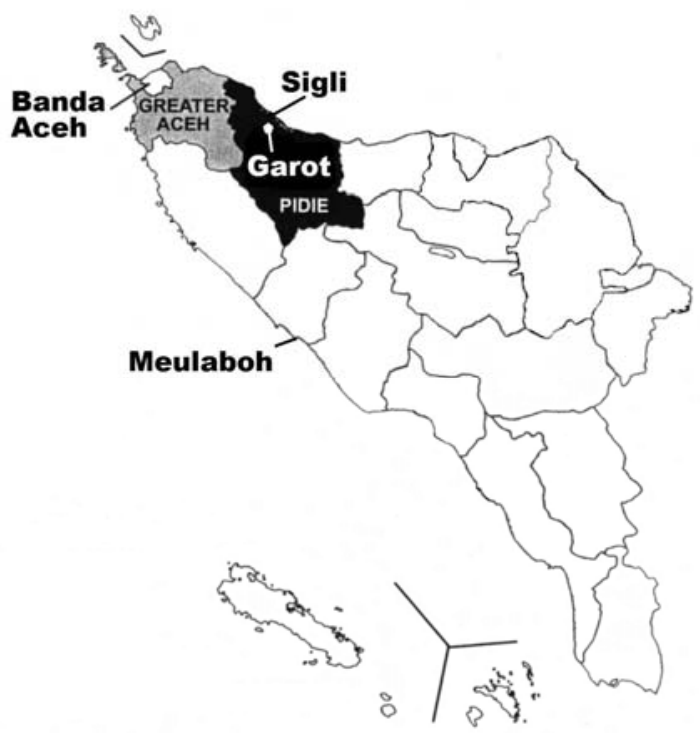

Figure 1. Aceh Province and the locations of Garot, Sigli and Meulaboh with regencies as of 2003.

\section{Production Place in Context}

Garot is said to be historically a part of "craft village” according to a Garot woman (85 as of 2010). Contrary to it, a report of a survey on local culture in 1980/1981, described that Garot was not rich in traditional crafts except for embroidery works and kopiah meuketob while it had played a role of producing important people and institutions in religious education (see Note 1-b). Perhaps as one of the consequences of this and other survey projects, the local government took an initiative to bring about in Garot a local cooperative for kasab (the gold thread stitch embroidery) in 1981. The first director of it was assigned to the above mentioned woman because she was one of the master kasab craftswomen in Garot.

According to this woman, people of Garot used to make songket, embroideries with golden thread, finger ring, bracelet, accessories, ornaments and rencong (Acehnese knife), but ceased to make them by the 1970s. It is likely that Garot area was once a center of the larger area based on the fact that it has an old market at the 
intersection of main roads and has also a place, like a small island surrounded by the rice field water, which has a remnant of the residence of once authoritative figure uleebalang. Interestingly this is contrary to my understanding that the traditional craft production sites are often seen to be left at the marginal area away from the original central production place in Japan (Cort, 1989; Sano, 1997).

Garot is connected to Sigli by an almost straight road along a river. Sigli, a coastal town and the present capital of Pidie Regency, which was largely suffered from the 2004 tsunami, is famous for the attitude among its men to be commerce-oriented and go out to work throughout Aceh. One example for this is tailors as mentioned earlier. As Reid illustrates, Pidie area, in which Sigli is located, falls in the middle between Banda Aceh and Pasai, an earliest commerce port town (in the thirteenth century) in Aceh (2000, p. 28). Pidie area is highly populated with flat lands suitable for wet rice cultivation (Davies, 2006, p. 46). It can be assumed that a group of man and woman including those who had knowledge of making crafts moved from a coastal port town like Sigli to an inland place like Garot during the period when, as Andaya insists, the kingdom shifted from outward commerce-oriented to inward agriculture-based life (2008, p. 142).

Women Kopiah makers in Garot and men tailors of Sigli origin seem to be unrelated with each other. However, it is likely that both of them may be derived from the rich craft making tradition established probably during seventeenth century of Aceh kingdom. This was made possible perhaps by the latitude brought by productive agricultural lands with dense population (see Figure 1). It is interesting to see that making Kopiah and the tailoring are not touched upon in historical studies on Aceh (Reid, 1969; 2005; 2010) and not fully described in art and craft studies such as Barbara Leigh's “Hands of Time: The Crafts of Aceh” (1989, p. 100). This volume only briefly mentions Kopiah in a jewellery section to explain the jewel ornaments attached to Kopiah. In this book, Leigh sorts the crafts into categories she set up but there is no appropriate category for Kopiah to fit in. Another volume on Acehnese art and craft also does not describe Kopiah though it uses a postal stamp of Teuku Umar with Kopiah on his head issued in 1961 to explain Acehnese war experiences (Smith, 1987, p. 10) and it suggests the use of Kopiah for men's ceremonial garb mentioning "A stylized cloth hat crown his head and jewellery is also worn for adornment” (Smith, 1987, p. 24).

One reason why Kopiah has been understated in the studies of Acehnese craft culture may be that the area close to Garot was a home of the leader of GAM (Indonesian abbreviation. (Aceh/Sumatra National Liberation Front)), and therefore it was difficult for non-Acehnese to visit the area and collect information of craft making in Garot during the 1980s (Aspinal, 2009, p. ix). In fact, almost all buildings of a college located several kilometers away from Garot were devastated during the conflict time. As of 2010, students of the college took classes still at the roofless school building sites. Even in such conflict time, as Garot women told, they kept manufacturing Kopiah and stacked it up at home. It is easy for them to adjust the number of pieces they make and to get materials at nearby market which are not special but general ones such as needles, scissors, threads, cloth of yellow, red, black and green colors as well as white, and kapok. They now make only the body part of Kopiah which is finished with golden plastic accessories at shops in Banda Aceh.

\section{Cultural Flow of Kopiah Image}

Kopiah has been a part of men's traditional costume. It is used for the second stage of wedding ritual after the first stage held inside a mosque (see Figure 2). The bride and bridegroom changed their outfits from Islamic style dresses to Aceh style. The bridegroom proceeded to the bride's village and sat in a chair receiving a welcome singing by a group of women at the gate and then he walked to the bride's house and into a decorated 
room for him and his entourages. I heard that it is not unusual for a bridegroom to borrow Kopiah from family members or friends.

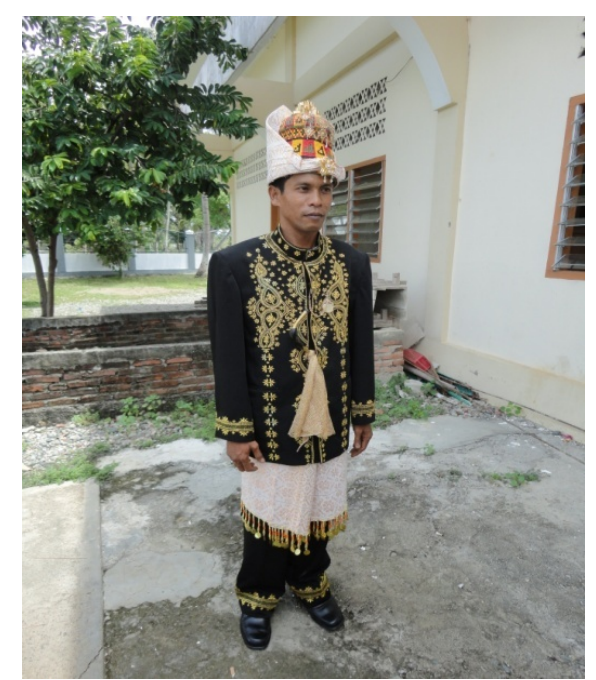

Figure 2. A bridegroom changed his attire to traditional costume with kopiah meuketob after the wedding ceremony at a mesjid behind to go for a ceremony at bride’s house (May 2010). Photo by Author.

Although I later had chances to see pictures of bride and bridegroom with Kopiah at the houses of acquaintances, I was not convinced that Kopiah is used only for wedding because I found that the image of Kopiah is used in various ways: on the head of politicians in the picture of street banners; on the head of young man in an advertisement billboard riding on the water buffalo cart; in the photos in brochures issued in the 1970s of local cultural activities in which local government staffs had Kopiah on their heads; and in a 1982's telephone book a telephone company's advertisement which has an illustration of a map of the whole Indonesia with two faces depicting an Irian Jaya man on the far east side and an Acehnese man with Kopiah on the far west side (see Figure 3). Moreover, Kopiah-like object, large and small, on the house roof, on top of house fences, to be used as house decoration. Far more than being used as decoration, the Kopiah-like object is used as the whole roof of a mosque (mesjid) in Banda Aceh and a bus stop near the Sultan Iskandar Muda airport. Other uses of Kopiah are a pattern of embroidery on Acehnese man's black hat and a pattern of newly-introduced batik to revitalize local industries (see Figure 4).

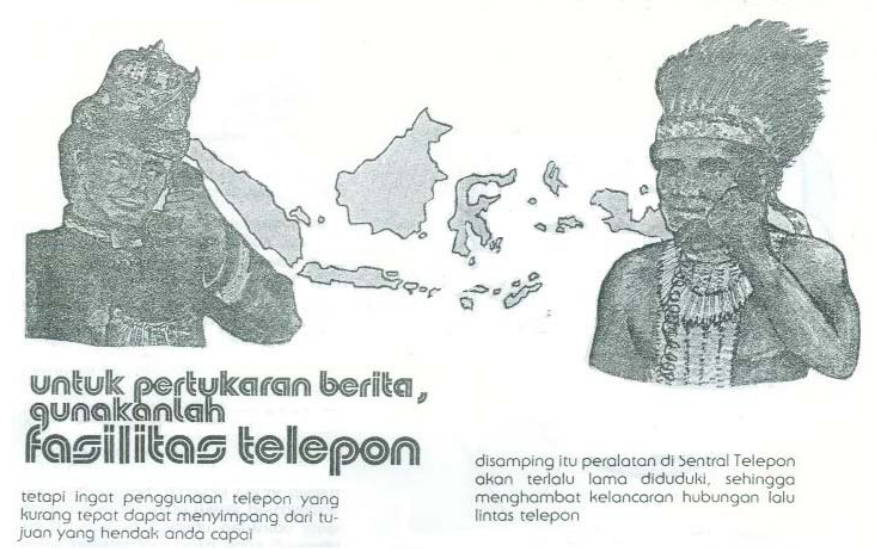

Figure 3. An Acehnese man with kopiah meuketob on the advertisement of 1982's local telephone book. 

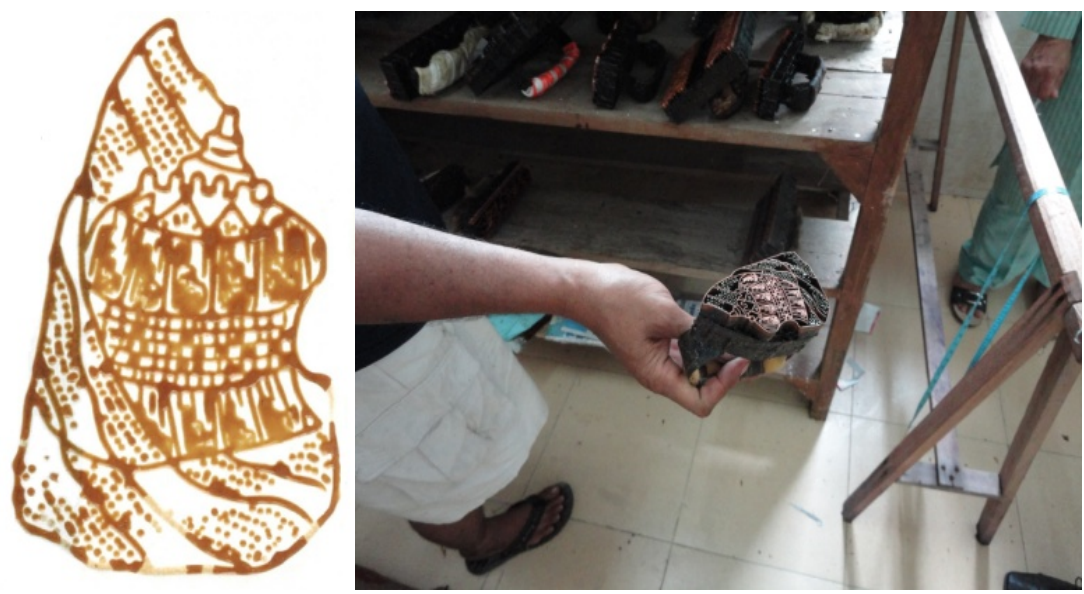

Figure 4. Wax image of kopiah meuketob and a newly-made batik cap for it. Photo by Author in 2010.

The case of a mosque with Kopiah-like roof illuminates a flexible nature of crafting in Aceh. For one anthropologist who is familiar with religious place such as Shinto shrine and Buddhist temple, the shape of such buildings varies but within the range of a stylized structure. On the other hand, in Aceh, local people, who collect money to build their mosque not only from local residents but also non-locals by standing on the road to ask them passing on car to throw money into buckets, can decide the kind of shape of the mosque. As to the Kopiah-like roof of the mosque in Banda Aceh (see Figure 5), a scholar and politician Ali Hasjmy who lived in its vicinity was a central planner to build this sizable mosque (construction period 1972-1983). His family member told that he got a hint from kopiah meuketob placed on his desk when he was wondering in what kind of shape the mosque would be. The episode shows that the local people are the agent of planning and fund raising for new local mosque and they are responsible to decide its outer shape. In this way, compared with monotonous and structured style of religious style, Acehnese people have various and flexible styles for their religious buildings.

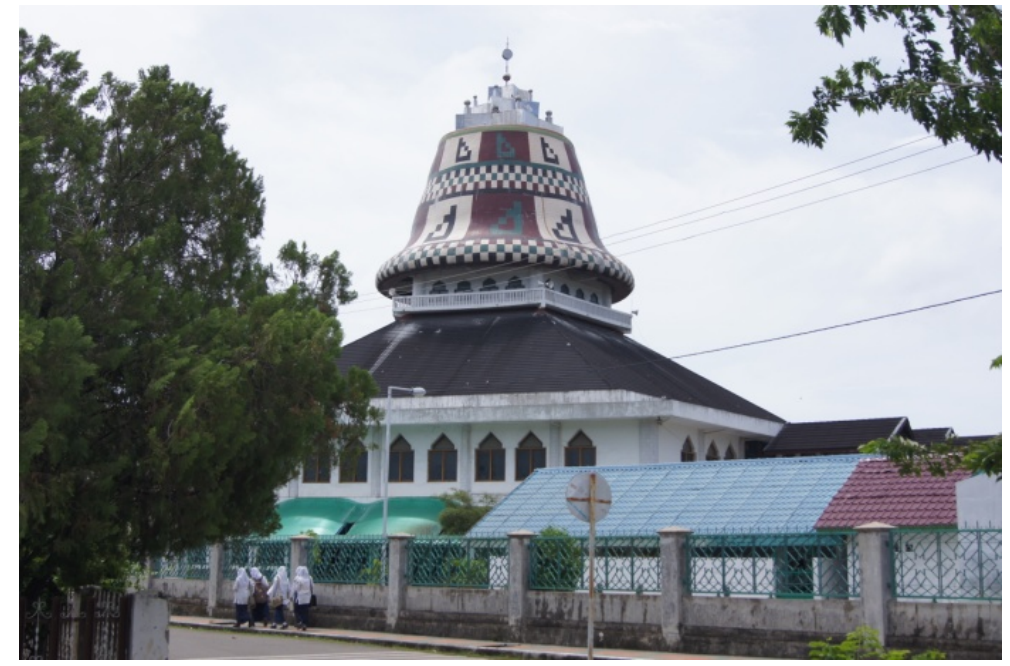

Figure 5. "Kopiah Meuketob” mesjid in Banda Aceh. Photo by Author.

The flexible use of Kopiah image goes apart from the ceremonial domain to other domains, such as assertion of cultural uniqueness, political independence, identity formation, unifying force, historical reminder, 
artistic pattern, and object of satirical art work. Especially after the 2004 tsunami, it has been accelerated for the Acehnese to be exposed to global encounters with aid-related personnel from different countries. The Acehnese themselves are consciously engaged in vitalizing local industries and tourism, and thus they need to rediscover their cultural assets and capitals to be used in various ways for getting into cultural global flows. Kopiah has come to be redefined as one of the symbols of Acehneseness, like a preceded image of Pintu Aceh (Acehnese door).

\section{Shaping Ethnicity and Kopiah}

To understand how Kopiah became part of Acehnese lives, let us assume that, in general, as people are forming ethnic identity, they try to express it in symbolic or concrete way such as using images or objects which are especially recognized or rediscovered as part of their authentic or traditional lives. When and how did the Acehnese make their ethnic distinctiveness? Andaya suggests that it was when Johor kingdom was being replaced with Aceh kingdom during the period from the end of the seventeenth century to the beginning of the eighteenth century that the Acehnese were forming their ethnicity and thus differentiating from neighboring cultural groups (2008, p. 144). Andaya argues that during that period the Acehnese were developing distinctive cultural characteristics while losing Melayu cultural traits (2008, pp. 144-145).

Following this, I have a proposition that the Acehnese would make a distinctive men's hat while they were creating their cultural uniqueness after they shifted the way of living from outgoing, hegemonic to domestic, agricultural. Pidie area has plenty flat lands and Garot is one of the rice-producing places in the area, which is free from oceanic hazards even if subjected to floods, fertile for wet rice cultivation, and conveniently located with crossroads. Toward the upstream in mountain side there used to be mines of gold, which might have been used for craft works in Garot. A senior Garot woman (80s) told that she recalled her grand-mother making Kopiah when she was a child, so it is likely that her grand-mother was teenager when she learned how to make Kopiah one hundred twenty or thirty years ago probably by seeing her grand-mother working on it (cf. Sano \& Matsumoto, 2015). Then it would be safe to say that Acehnese people had created Kopiah by the middle of the nineteenth century. This is accord with a photo dated ca 1880 (displayed in a museum in Banda Aceh) showing a man with Kopiah on his head.

The original Kopiah is said to be like kopiah syam, made of cloth from Siam (Thailand), whose height was lower than the present Kopiah (see Note 1-a). Kopiah syam might have been made during the eighteenth century. It is likely that kopiah syam existed because the hat displayed in the National Museum in Jakarta (as of 2011) is similar to it. So it is hypothesized that there had to be a change from the dome-shape to the taller shape over time. Except for its height, similarities are recognizable between the supposedly original and the present Kopiah in the color combination and patterns, decorative gem on the top and the shape of each layer of the body. A notable difference is the decoration material: the real gems on the top of the old while the plastic on the recent. Although the body structure looked very similar, the width of patchworks of the one displayed in the museum is narrower and finer in handiwork than the present.

Andaya mentions that elephants were important export from Aceh kingdom based upon a letter to Dutch official in Batavia (Jakarta) dated 1640, and also that a lot of Indian cloth was imported to Aceh to meet the need, especially the need of people in Samudera Pasai (a Muslim kingdom on the north coast of Sumatra), whose realm overlaps the present Pidie area (2008, p. 137). Multitude of the imported cloth suggests that 
people of the area did not weave enough cloth. The tendency to shift from relying on weaving to importing cloth seems to be similar to the change in Jambi during the seventeenth and eighteenth centuries (Andaya, 1989). If this way of living has been carried on over generations in the area, it makes sense that we do find few traditional weaving women in present Aceh. Garot women have been making Kopiah using cloth and threads traded probably from India or Siam. It would not be wrong to say that they succeed the traditional way of using foreign cloth, which probably has been developed since the thirteenth century. In the same sense, tailoring and embroidering have been also part of the traditional way of using foreign cloth and threads.

The origin of materials for making Kopiah seems to be hardly concerned by women in Garot. This is accord with the receptive attitude among Acehnese people toward a fact that the Acehnese culture was influenced by different cultural elements namely Arabic, Chinese, European and Hindu elements. In other words, it is important to obtain appropriate materials for the traditional things rather than to keep using the materials originated from Aceh. Changing and revising the materials for culturally distinctive, traditional things is accepted as far as the traditional forms of the things are preserved.

As to shaping Acehnese ethnicity, what Andaya (2008) tried to show about Aceh in the seventeen century is applicable to its post-WW II condition from 1958 to the 2010s. In 1958 the first Aceh Cultural Week (Pekan Kebudayaan Aceh) was held. An article about Acehnese clothes (see Note 1-i) states that this event was an occasion for Acehnese people to reflect on their cultural awareness and return to traditional customs, that is, to redefine their cultural identity. Since then, to fulfill the autonomous status of Aceh has been an important issue especially in the areas of religion, customs and education. In 1984, a panel discussion was held on the motif of Acehnese clothes in Banda Aceh. One of the issues was how traditional culture was made use of for the contemporary life. In the third Aceh Cultural Week in 1988, both customary and ordinary clothes were included in approximately 100 kinds of exhibits perhaps because the event was still an occasion for the Acehnese to find the ways of managing new clothes with traditional ones. Such clothes issues continue to be discussed in Aceh in relation to the matter of what the Acehnese socio-cultural life should be like. For instance, in 2009, a controversial issue arose over the free distribution of women's skirt attempted by a regency government against the trend of wearing trousers among local women (see Note 1-k, pp. 7-9).

Throughout these years and especially post-tsunami years, reshaping ethnicity among the Acehnese has been consciously practiced (Ichwan, 2011; Merry \& Millligan, 2009; Missbach, 2011). For it, the Aceh Cultural Week (Pekan Kebudayaan Aceh) is exemplary. The first and the second of it were held in 1958 and in 1972 respectively. The subsequent festivals were held the same sixteen-year apart: between the second and the third (1988); between the third and the fourth (September 2004). However, it took only five years from the fourth to the fifth (2009), and the interval became even shorter, four years between the fifth and the sixth (2013). Moreover, a large fashion show "Exploration of Aceh Culture on Moslem Fashion” was held in Banda Aceh in May 2011, in which fashion designers presented new designs emphasizing Acehnese cultural traits. Kopiah which is considered as part of traditional customary clothes was not used for the fashion show which is considered to be for women. However, Kopiah became an element representing traditional Acehnese ethnicity for modern fashion designs for men as seen in a fashionable costume which was designed by a local student and a parade participant worn for the sixth 2013 Aceh Cultural Week (see Figure 6). 


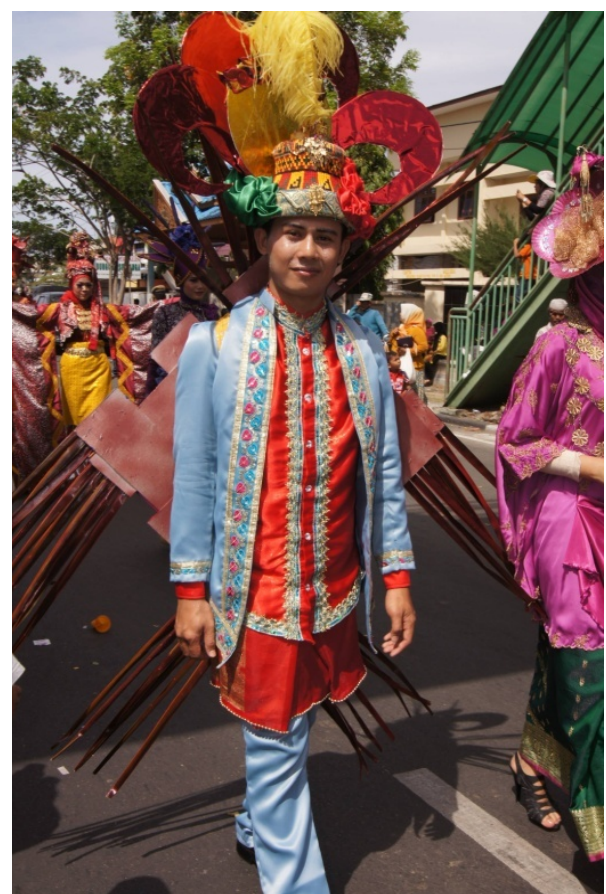

Figure 6. A parade-participating man with kopiah meuketob in a student-designed costume at the sixth Cultural Festival of Aceh in Banda Aceh, September 2013. Courtesy by Y. Matsumoto.

\section{Characteristics of Kopiah}

The structure of Kopiah seems to be complicated at first glance because it consists of five vertical layers including the top called Tampok, crown-like decoration. Its overall shape looks like a three-dimensional patchwork with vertical dented lines. The part of vertical stripes is made of combinations of yellow, red, black, white and green small cloth. The combination of colors differs from adjacent vertical stripe parts, so the overall body of the Kopiah has mosaics of five colors with the repeated patterns. However, the way of making it reveals that techniques and tools women need are relatively simple. They have to cut color cloth on the bias in eight or ten mm square and to be patient in sewing the pieces of cloth into the patterned combination (see Figure 7). Then kapok sticks which are made with the top thinner than the bottom are wrapped vertically in the pieces of cloth. Each piece of cloth is sewn up backside wrapping a kapok stick inside. The construction process is made possible by the stretch-ness of the cloth pieces produced by the biased cutting.

A manuscript about Kopiah (see Note 1-l), a copy of which was kept by a senior Garot woman, was said to be written by a historian probably in the late 70s or early 1980s. As the woman mentioned, in these years under Sukarno regime, there were official surveys of local cultures worth being preserved. The surveys were taken place all over the country and the manuscript was probably written as a response to the survey project. The manuscript about Kopiah explains meanings of patterns on different parts and an estimation of the origin of Kopiah based on the overall objective resemblance with architecture in Middle East whose picture the author discovered. The patterns on the body of the architecture in a monochrome picture in the manuscript actually resemble the patterns of Kopiah's body part. However, the outer shape of the architecture is triangle while the shape of Kopiah is round. The author mostly explained the meanings of the patterns in terms of religious doctrines and teachings. It is not clear that such religious symbolic connections came merely from the author's interpretations or from the author's collections of information from other people. 


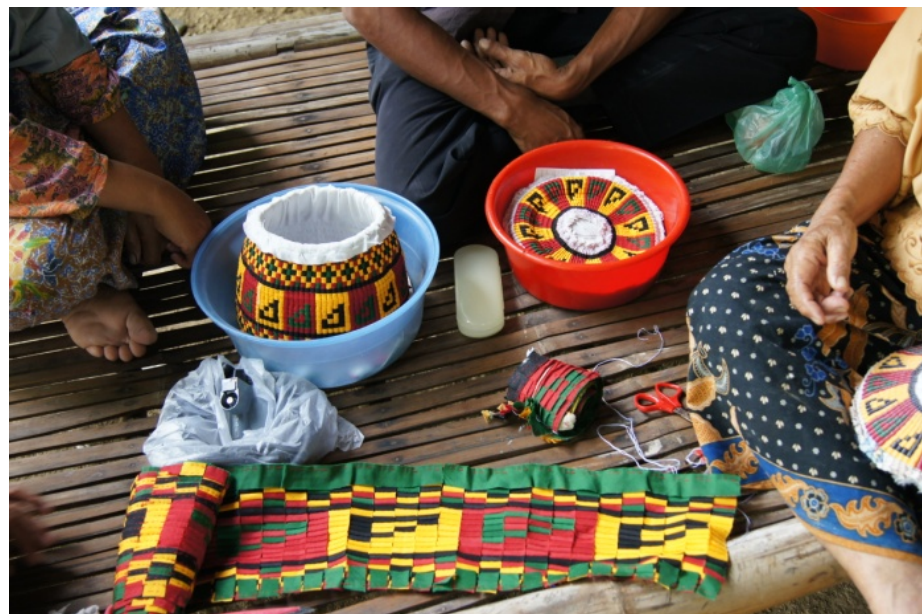

Figure 7. Garot women showing tools and materials as well as assembling process of kopiah meuketob. Photo by Author.

The shape of Kopiah and the patterns on it are laden with social, cultural and religious meanings according to literatures about Kopiah and the feature of Acehnese wedding (see Note 1-c h). For instance, each layered part of it is explained to have a social meaning: the bottom layer represents Islamic laws, the next layer from the bottom represents customary laws, the third represents norms, and the top layer represents general rules. The colors used for Kopiah symbolize cultural meaning: yellow symbolizes king and nobles, green symbolizes Islam, red symbolizes courage and hellos, and black symbolizes people. The number of the vertical strips of Kopiah body part is ninety-six, implying that ninety-six kapok sticks are used. It is said that the number of ninety-nine parts, which include the ninety-six vertical stripes and three decorations attached to Kopiah, coincides with the number of ninety-nine names of Allah. So it is thought to be virtuous to say one of ninety-nine names of Allah as women is proceeding to work on wrapping a kapok stick with pieces of cloth. However, this virtue could not be achieved now because the finishing work with decorations takes place outside of the village. Other two patters are distinctive and each has meaning (see Note 1-l). A unit of six vertical stripes brings about sixteen of a keyhole-like pattern on the second and fourth layers from the bottom of Kopiah. This pattern is said to be associated with the name of Allah. A unit of four vertical strips brings about twenty-four of a pepper-flower-like pattern on the first and third layers. This pattern is said to have meanings of spirit and courage.

If such religious meanings are transmitted over generations among Garot women, it is suggested that Kopiah making is one of religiously important practices. However, as far as I can judge from the information I and my colleague gathered from woman who make Kopiah, they hardly have knowledge about the meanings of colors, patterns and the part's numbers. Garot women seem to be indifferent to the overall meanings attached to Kopiah although some of them told that they heard of the virtuous aspect of Kopiah making. I did not observe them practicing any religious rituals related to Kopiah. Thus it is likely that there is no direct relationship between making Kopiah and religious practices.

\section{Flexible Ways of Participating in Piecing Kopiah}

I first met women in Garot who made kasab and Kopiah when I and my colleagues visited the village with an introduction of administrative staffs in charge of the promotion of local crafts in May 2010. After we met a 
woman who was a head of a cooperative for kasab makers, we went to a house where a woman showed us her Kopiah in progress and materials for it, and then several women neighbors in the same middle age came one by one, and they showed how to make Kopiah. At that time, I came to know that those who made crafts such as kasab and Kopiah were all women although there was a male tailor who made men's formal attire of traditional Acehnese style in a nearby village. I assumed that the women who make Kopiah are in their middle-age, work in a group helping each other, and are members of a sort of cooperative organization. However, through two more visits to the village in the same year and the following year, I realized that women who make Kopiah are diverse in age, from twenties to eighties, and that the degree to which these women are engaged in making Kopiah depends upon individual decision: only sewing pieces of cloth, or doing a few processes, or even doing all processes. And some of them work to make Kopiah in a group while some of them do individually. For making Kopiah, there is neither an organization like the cooperative for kasab nor a system like a putting-out system (Waterbury, 1989).

Interestingly Kopiah made in Garot was not included in the promotion list of local industries for which a survey of the local cultural resources was officially carried out in the late 1970s (see Note 1-b). This survey probably led the local governmental initiative to establish a kasab cooperative in Garot as mentioned earlier. However, Kopiah making was left to local women's free activity although it was briefly described in the survey report. The reason for it was perhaps because Kopiah was considered as a traditional customary craft and too local to be commercially promoted beyond the local boundary.

Both individual and group work rhythm of making Kopiah is fitted to women's daily, weekly, seasonally and yearly rhythm of agricultural works in Garot. Many Garot women, especially in their middle age, are engaged in wet rice agriculture and working for their domestic lives. Group works are important for their lives because they are considered as social, that is, reciprocal aid practices in various events and occasions such as cultivation, planting and harvesting as well as wedding and initiation rituals (e.g., Nazamuddin \& Syamsuddin, 2010, p. 83). The time of making Kopiah is found in spare time, so that elderly women tend to be a full time Kopiah maker often accompanied by onlookers of granddaughter's generation. The flexible use of time for making Kopiah has been long a basic way of living in Garot probably since wet rice agriculture began to be promoted and became integrated in Acehnese social life in the late seventeenth and the early eighteenth century. Their matriarchal way of life has played a role of bringing a sense of affection for Garot, which has been complemented with their belief that men travel to find employment, do commercial business, and train themselves so that they gain successful lives outside (Aspinal, 2009, p. 93; Schröter, 2010, p. 162).

Garot women used to spend two or three months to finish one Kopiah at least up until 1980 when a literature about Kopiah (see Note 1-a) was written, explaining that the reason of such length of time needed was because there were many small pieces of materials for women to prepare, handle and process. Now the working time is reduced to several weeks to make one. This suggests that the process of making Kopiah has been simplified and the agricultural works have become less heavy than before. In fact, harvesting rice twice a year was banned by the regency government in 1979 because of too much burden for villagers (see Note 1-b).

Simplification of craft making process is often pointed out to go hand-in-hand with the degradation or the loss of fineness. In case of Kopiah, as the process of making it has been actually simplified or more precisely less elaborated, compared with the Kopiah exhibited at the National Museum which was apparently made by skillful workers. However, the degradation of Kopiah had been supposedly ceased in a certain period at the present quality level so that ordinary women became able to participate in any stages of Kopiah making process. 
During this process, decorations and accessories became plastic imitations of gems and gold chains. Further changes are seen in a production of miniature Kopiah from around 2010 which the recent tourist-oriented activity brings about. This degradation is accepted for the miniature as a souvenir but surely not for the traditional one.

The commoditization of the Kopiah is apparently evidenced by a change in the way of wearing Kopiah. Wearing Kopiah is now as simple as wearing a baseball cap because Kopiah which is available at store is all set with accessories and a cloth tangkulok with gold thread embroidery wrapped round the lower part of Kopiah. However, before not so long, this cloth had not been readily wrapped around the Kopiah. Men had to wrap a cloth by themselves around the bottom part of Kopiah, as demonstrated by a Garot man in middle age to me. According to him, it was required for men to cover the head with a cloth to show respect to other people when they were in situations such as they talk to their parents and parent-in-laws. The custom of wrapping the head with cloth is commonly practiced among men of Southeast Asian cultural groups. The folding style of the cloth around the head is unique to each cultural group but the use of cloth seems to be shared among many cultural groups (Maxwell, 1990, p. 309). In this point, the present Kopiah can be categorized as one of Southeastern men's hat style. Nevertheless, Kopiah without the cloth belt is the one which Acehnese hero Teuku Umar wore in the end of the nineteenth century. Although it is difficult to determine when Kopiah began to be attached with the cloth tangkulok, it is likely that the present ready-made Kopiah was created as more men came to have chances to use it and thus it became commoditized.

The simplification of Kopiah making process implies not only pervasiveness of craft making skills among ordinary women and flexibility of women's participation in making process but also popularization of its use among ordinary men namely for wedding. Given that Kopiah was originally limited to the use of king and noble men, I assume that its exclusive use shifted to the inclusive one, that is, it became to be used by ordinary men as Aceh kingdom declined during the eighteenth and nineteenth centuries. It is difficult to know when this shift took place in such a long declination. However, as a photo of Acehnese bridal couple indicates, the Kopiah had become a part of bridegroom's wedding costume as early as in the middle of the nineteenth century. I would insist that two centuries were needed to create and recreate Acehnese cultural features and identity and meanwhile the style of wedding attires changed over time and eventually in the nineteenth century became the one we see now.

\section{Conclusion}

The longevity of kopiah meuketob (Kopiah so far) has been sustained by women in Garot and how those women have been engaged in making it is mainly featured by the adjustments they have made flexibly throughout difficult times at least since the end of the nineteenth century over war time, conflict time and natural disasters such as floods and earthquake. They seem to keep an exclusive circle of craftswomen in a sense that women outside of Garot are not interested in making it except for Meulaboh. However, Garot women can equally participate in making it as they want, individually and in group, part-time and semi-full-time, in a certain production process and in all processes. Participating women are in all range of adult ages and have no problem with teaching expected successors because village young girls learn by watching older women piecing kopiah meuketob in different manufacturing stages outside the house under the roof. The women are free from organizational requirements, rules and regulations. Even though the selling price goes down, the women keep their pace of making it and nowadays take orders easily with mobile phones from people in distant towns. The 
materials needed for making kopiah meuketob are not special in a sense that they should not be necessary to be locally produced. Imported materials have been used. In this sense the longevity of kopiah meuketob has been linked to the world globally. It has been also sustained by Acehnese people who have been active in practicing a custom associated with kopiah meuketob and have flexibly extended the use of its images and objects into a cultural flow shaping a regional "craft-scape". This kind of sustainable craft making is surely backed up by fertile local terrains. Thus in other places, this kind of making things and living sustainable is not appropriate to take as it is but to do similar way, namely flexible participation in production processes, would be worth trying.

\section{Notes}

1. I obtained information of kopiah meuketob and Garot from the following sources in Indonesian (listed in order of publication year due to the naming custom different from Euro-American type) with the assistance of Yuka Matsumoto. I used the information collectively to describe kopiah meuketob and Garot in this essay.

(a) ZZ. Muhammad. (1980). Seni Rupa Aceh II Kabupaten Pidie (Art of Aceh II Pidie Regency): Departemen Pendidikan dan Kebudayaan, Direktorat Jenderal Kebudayaan Taman Budaya, Banda Aceh: 47-50.

(b) Mc. Suprapti (Ed.). (1980/81). Pola Pemukiman Penduduk Pedesaan Daerah Propinsi D. I. Aceh (Forms of rural population in D. I. Aceh Province): Departemen Pendidikan dan Kebudayaan Proyek Inventarisasi dan Dokumentasi Kebudayaan Daerah.

(c) ZZ. Muhammad. (1981) Seni Rupa Aceh IV Kabupaten Aceh Barat (Art of Aceh IV West Aceh Regency): Departemen Pendidikan dan Kebudayaan, Direktorat Jenderal Kebudayaan Taman Budaya, Banda Aceh.

(d) M. Ahmad Yunus, \& Tatie Kartikasari. (1985/86). Pakaian Adat Tradisional Daerah Propinsi Daerah Istimewa Aceh (Traditional customary clothes of D. I. Aceh Province): Departemen Pendidikan dan Kebudayaan Direktorat Jenderal Kebudayaan Direktorat Sejarah dan Nilai Tradisional Proyek Inventarisasi dan Dokumentasi Kebudayaan Daerah: 23, 33.

(e) Tatiek Kartikasari, \& H. Ahmad Yunus. (1986/87). Arti Perlambang dan fungsi Tata Rias Pengantin dalam Menanamkan Nilai-Nilai Budaya Propinsi Daerah Istimewa Aceh (Symbolic meaning and role of ornamental style of bride and bridegroom rooted in cultural values of D. I. Aceh Province): Departemen Pendidikan dan Kebudayaan Pusat Penelitian Sejarah dan Budaya Proyek Inventarisasi dan Dokumentasi Kebudayaan Daerah: 46.

(f) Yayasan Meukuta Alam Himpuan Ahli Rias Pengantin Indonesia "Melati” Yayasan INSANI. (1990). Tata Rias dan Upacara Perkawinan Aceh (Ornamental style and ceremonial rite of Acehnese wedding).

(g) T. Alamsyah Talsya, \& Abdul Jalil (Ed.). (1991). Pedoman Umum Adat Aceh Edisi 1 (Guide of general customs in Aceh, 1st edition): Lembaga Adat dan Kebudayaan Aceh (LAKA) Propinsi Daerah Istimewa Aceh: 31.

(h) Museum Negeri Propinsi Daerah Istimewa Aceh 1991/92 Pameran Khusus Pakaian Adat Aceh dan Perkembangnnya (Special exhibition of traditional clothes in Aceh and its blossoming): Departemen Pendidikan dan Kebudayaan Bagian Proyek Pembinaan Permuseuman Daerah Istimewa Aceh: 62.

(i) Teuku Alibasjah Talsya. (1993). Pakaian Aceh (1) (Clothes in Aceh 1), JEUMALA 7: 8-10; Pakaian Aceh (2) (Clothes in Aceh 2), JEUMALA 8: 19-22.

(j) H. Badruzzaman Ismail, \& S. H. M. Hum. (2009). Panduan Adat dalam Masyarakat Aceh (Guide of 
Customs in Acehnese Society): Diterbitkan oleh Majelis Adat Aceh (MAA) Provinsi Nanggroe Aceh Darussalam: 4-5.

(k) Tabrani Yunis. (2009). Bertanya Rok Gratis Bupati (Inquiry about governor's free skirt). POTRET, 29, 7-9. Media Perempuan Aceh. Center for Community Development and Education.

(l) Anonymous. (n.d.). Penafsiran Lukisan (Interpretation of monograms). (a copy of the manuscript was provided by a local elderly woman in May 2010 at Garot).

\section{References}

Andaya, B. W. (1989). The cloth trade in Jambi and Palembang society during the seventeenth and eighteenth centuries. Indonesia, 48, 27-46.

Andaya, L. Y. (2008). Leaves of the same tree: Trade and ethnicity in the straits of Melaka. Honolulu: University of Hawai'i Press.

Appadurai, A. (1996). Modernity at large: Cultural dimensions of globalization. Minneapolis: University of Minnesota Press.

Aspinall, E. (2009). Islam and nation: Separatist rebellion in Aceh, Indonesia. Stanford, Cal.: Stanford University Press.

Cort, L. A. (1989). The changing fortunes of three archaic Japanese textiles. In A. B. Weiner and J. Schneider (Eds.), Cloth and human experience (pp. 377-415). Washington \& London: Smithsonian Institution Press.

Davies, M. (2006). Indonesia's war over Aceh: Last stand on Mecca's porch. Oxford: Routledge.

Ichwan, M. N. (2011). Official ulema and the politics of re-Islamization-The Majelis Permusyawaratan Ulama, Shariatization and contested authority in post-new order Aceh. Journal of Islamic studies, 22(2), 183-214.

Kates, R. W., Parris, T. M., \& Leiserowitz, A. A. (2005). What is sustainable development? Goals, indicators, values, and practice. Environment. Retrieved from http://www.environmentmagazine.org/edtorials/kates-spr05-full.html

Latour, B. (2005). Reassembling the social: An introduction to actor-network-theory. New York: Oxford University Press.

Leigh, B. (1989). Tangan-Tangan Trampil: Seni Kerajinan Aceh (Hands of time: The crafts of Aceh). Jakarta: Djambatan.

Maxwell, R. (1990). Textiles of southeast Asia: Tradition, trade and transformation. Oxford: Oxford University Press.

Merry, M. S., \& Milligan, J. A. (2009). Complexities of belonging in democratic and democratizing societies-Islamic identity, ethnicity and citizenship in the Netherlands and Aceh. Journal of Muslim Minority Affairs, 29(3), 311-323.

Missbach, A. (2011). The Acehnese diaspora after the Helsinki memorandum of understanding: Return challenge and diasporic post-conflict transformations. Asian Ethnicity, 12(2), 179-201.

Nazamuddin, A., \& Syamsuddin, M. (2010). Economic modernization and its influence on the social system in Aceh. In A. Graf, S. Schröter, and E. Wieringa (Eds.), Ache: History, politics and culture (pp. 81-98). Singapore: ISEAS Publishing.

Reid, A. (1969). The contest for north Sumatra: Atjeh, the Netherlands and Britain 1858-1898. Oxford: Oxford University Press.

Reid, A. (2000). Charting the shape of early modern Southeast Asia. Chiang Mai, Thailand: Silkworm Books.

Reid, A. (2005). An Indonesian frontier: Acehnese and other histories of Sumatra. Singapore: Singapore University Press.

Reid, A. (2010). Imperial alchemy: Nationalism and political identity in Southeast Asia. Cambridge: Cambridge University Press.

Reid, A. (2015). A history of Southeast Asia: Critical crossroads. Chichester: John Wiley \& Sons.

Sano, T. (1997). Women and revival of traditional cloth making in the Philippines and Japan. In Proceedings of International Conference on Women in the Asia-Pacific Region: Person, Powers and Politics (pp. 492-501). Department of Geography, South East Asian Studies Programme, Center for Advanced Studies of National University of Singapore.

Sano, T., \& Matsumoto, Y. (2015). Changes in the way of traditional cloth makings and the weavers' contribution in the Ryukyu Islands. In Textile Society of America, Textile Society of America $14^{\text {th }}$ Biennial Symposium Proceedings. DigitalCommons@University of Nebraska_Lincoln (Retrieved from http://digitalcommons.unl.edu).

Schröter, S. (2010). Acehnese culture(s): Plurality and homogeneity. In A. Graf, S. Schröter, and E. Wieringa (Eds.), Aceh: History, politics and culture (pp. 157-179). Singapore: ISEAS Publishing.

Smith, H. S. (1997). Aceh: Art and culture. Oxford/New York: Oxford University Press.

UNDP. (2011). Human development report 2011, sustainability and equity: A better future for all. New York: United Nations Development Programme.

Waterbury, R. (1989). Embroidery for tourists: A contemporary putting-out system in Oaxaca, Mexico. In A. B. Weiner and J. Schneider (Eds.), Cloth and human experience (pp. 243-271). Washington and London: Smithsonian Institution Press. 